8. Монтанари М. Голод и изобилие. История питания в Европе. СПб.: Изд-во «Александрия», 2009. 288 с.

9. Ле Гофф Ж. Цивилизация средневекового Запада. М.: ИД «Прогресс-академия», 1992. 376 с.

10. Дюби Ж. Европа в средние века. Смоленск: Изд-во «Полиграмма», 1994. 320 с.

11. Поньон Э. Повседневная жизнь Европы в 1000 году. М.: Изд-во «Палимпсест», 1999. 384 с.

12. Григорий Турский. История франков. М.: Издво «Наука», 1987. 464 с.

13. Venantius Fortunatus. Vita Sanctae Radegundis // Monumenta Germaniae Historica. Vol. 1. Hannoverae: Impensi Bibliopolii Hahniani, 1888. P. 364-377.

14. Сидоний Аполлинарий. Книга V, Письмо 17. К Эрифию // Памятники средневековой латинской литературы IV-IX веков. М.: Наука, 1970, С. 96-98.

15. Салическая правда / Пер. Н.П. Грацианского; под ред. В.Ф. Семенова. М.: Изд-во: «Образцовая тип. им. Жданова», 1950. 168 с.

16. Борисенков Е.П., Пасецкий В.М. Тысячелетняя летопись необычайных явлений природы. М.: Изд-во «Мысль», 1988. 522 с.
17. Сидоров А.И. В ожидании Апокалипсиса. Франкское общество в эпоху Каролингов. VIIIХ века. М.: Изд-во «Наука», 2018. 226 с.

18. Послание о вкусной и здоровой пище достопочтенного комита и посланника Анфимия славному Теодориху, королю франков // Горелов Н.С. Закуска для короля, румяна для королевы. СПб.: ИД «Азбука-классика», 2008. С. 107-120.

19. Венанций Фортунат. Еще одно, о каштанах // Венанций Фортунат. Избранные стихотворения. Кн. XI, XIII. М.: Изд-во «Водолей», 2009. С. 174.

20. Венанций Фортунат. К нему же // Венанций Фортунат. Избранные стихотворения. Кн. VII, VIII. М.: Изд-во «Водолей», 2009. С. 142-144.

21. Джонсон Х. История вина. М.: Изд-во «BВPG», 2004. $480 \mathrm{c}$.

22. Венанций Фортунат. Еще к ней же, чтоб пила вино // Венанций Фортунат. Избранные стихотворения. М.: Изд-во «Водолей», 2009. Кн. XI, IV. С. 169.

23. Бродель Ф. Структуры повседневности. Материальная цивилизация, экономика и капитализм XVXVIII вв. Т. 1. М.: Изд-во «Прогресс», 1986. 622 с.

\title{
THE DAILY LIFE OF THE FRANCS ACCORDING TO WRITTEN SOURCES AT THE TIME OF GREGORY OF TOURS: DISEASES, MEDICINE, HYGIENE AND FOOD
}

(C) 2019

Kazakov Igor Valentinovich, candidate of historical sciences, associate professor of World History, Law and Methods of Teaching Department Samara State University of Social Sciences and Education (Samara, Russian Federation)

Abstract. This paper is an attempt to collect and systematize information about the material conditions of life in the Frankish state of the Merovingians in the $6^{\text {th }}$ century. The choice of the topic is due to the need to compose a complete picture of a person's life from the beginning of the early Middle Ages, which until now has remained poorly researched, unlike the Carolingian period. The sources used are the writings of Gregory of Tours, Venantius Fortunatus, Apollinaris Sidonius, The Chronicle of Fredegar, «The History Book of the Franks» and others. The paper contains data on the diseases and epidemics that were widespread during the mentioned period, methods of their treatment and the state of medicine in general, hygiene in the Frankish society, as well as the diet and composition of products. The collected material says that: a) the sources of the early Merovingian period are extremely scarce data in the field of life descriptions; b) the Frankish society was very vulnerable to a wide variety of diseases, and the priority of faith over medicine did not allow them to resist; c) ideas about the absence of elementary hygiene in the early Middle Ages are greatly exaggerated, and d) the set of consumed products was distinguished by simplicity and at the same time diversity with rudimentary skills in cooking.

Keywords: Merovingians; Gregory of Tours; Fredegar; Venantius Fortunatus; The History Book of Franks; daily life; Frankish state; early Middle Ages; diseases; epidemics; medieval medicine; medieval hygiene; food in middle ages; The Salic law; material conditions; $6^{\text {th }}$ century.

УДК 94 (367) : $929.5 \ll 15 »$

DOI 10.24411/2309-4370-2019-11203

Статья поступила в редакцию 09.12.2018

\section{К ВОПРОСУ О ПРОИСХОЖДЕНИИ КНЯЗЯ МИХАИЛА АНДРЕЕВИЧА ЛЕТОПИСНОЙ СТАТЬИ 1305 ГОДА}

(C) 2019

Абуков Сергей Навильевич, кандидат исторических наук,

доцент кафедры историографии, источниковедения, археологии и методики преподавания истории Донецкий национальный университет (2. Донеик, Донецккая Народная Республика)

\footnotetext{
Аннотация. Среди многих спорных вопросов отечественной генеалогии особое место принадлежит проблеме происхождения князя Михаила Андреевича летописной статьи 1305 г., о котором известно, что он женился в Орде и приехал в Нижний Новгород, где казнил восставших жителей. Проблема его происхождения связана с ранней историей династии суздальско-нижегородских князей и наследованием власти на Руси в эти годы. Вообще, история русских земель в XIII-XIV вв. слабо освещена источниками, и каждый новый факт дополняет наше представление об этом периоде. Имя отца князя не упоминается в источниках. В научной литературе существуют два противоположных мнения, которые невозможно объединить. Одни историки считают этого князя сыном Андрея Александровича Городецкого и внуком Александра Невского, другие -
} 
сыном Андрея Ярославича Суздальского, брата Александра Невского. В статье автор на основании критического анализа источников и аргументов историков приходит к выводу о том, что Михаила Андреевич - это сын Андрея Городецкого, который приехал в город своего отца. Об этом говорит присутствие его имени в синодиках, его упоминание в эти годы, связь с уделом городецкого князя, брачная политика и др. Напротив, Михаил Суздальский упоминается задолго до 1305 г. и не имеет отношения к Нижнему Новгороду, который в начале XIV в. еще не входил в состав Суздальского княжества. По мнению автора, князь рано умер и не является предком суздальских князей.

Ключевые слова: Михаил Андреевич; Андрей Ярославич; Андрей Александрович; Михаил Ярославич; Василий Михайлович; Суздаль; Нижний Новгород; Москва; Суздальско-Нижегородское княжество; Орда; XIV век; проблема; сын; отец; князь; династия; княжество; власть; город; происхождение; генеалогия; родство.

Краткое сообщение летописной статьи 6813 года: «В Новегороде Нижнемъ черные люди побили бояръ, пришедше же князь Михаило Андреевичь из Орды в Новгородъ в Нижнии и изби вечниковъ» [1, c. 393] не раз привлекало историков. Это известие дополняется другим - 6814 года: «Того же лета ожениса князь Михайло Аньдреевичь во орде, и приде в Новъгородъ, и изби вечникы» [2, стб. 58]. Для советских историков-марксистов события в Нижнем были ярким подтверждением теории классовой борьбы [3, c. 462]. Однако больше всего споров вызывало происхождение князя Михаила Андреевича, особенно в контексте проблемы генеалогии династии суздальско-нижегородских князей, которая уже не один век занимает историков. Вопрос представляется настолько сложным, что многие исследователи предпочитали обойти его стороной или просто примкнуть к одному или другому мнению. Однако ответ на него важен не только в связи генеалогией. В более широком контексте он затрагивает споры о существовании в начале XIV в. Суздальско-Нижегородского княжества и политической ситуации в Поволжье в начале XIV в., практически не освещенной источниками.

Так как в вопросе генеалогии Михаила Андреевича невозможно найти компромисс, то историки разделились на два лагеря. Сына великого князя Андрея Ярославича Суздальского видели в нем: Н.М. Карамзин [4, с. 102], Н.И. Храмцовский [5, с. 13], П.Н. Петров [6, с. 227], А.В. Экземплярский [7, с. 388389, прим. 1086], А.Е. Пресняков [8, с. 178], Г.В. Абрамович [9, с. 17-20], Н.Ф. Филатов [10, с. 29]; Е.В. Шматов [11, с. 70]; Д.С. Таловин [12]; Л.В. Войтович $[13$, с. 571$]$, Ф.А. Селезнев $[14$, с. 66]. Наоборот, сыном великого князя Андрея Александровича Городецкого, племянника Андрея Ярославича Суздальского, считали Михаила: С.М. Соловьев [15, с. 218-219], В.А. Кучкин [16, с. 206-209], Б.М. Пудалов $[17$, с. $52-53]$, А.А. Горский $[18$, с. 42]. Как видим, большинство исследователей считали Михаила племянником Александра Невского, а не его внуком. Только некоторые исследователи давали развернутую аргументацию. Можно заметить, что нередко мнение о происхождении князя Михаила выражалось безапелляционно и перешло в различные популярные издания. Кроме того, часть историков видела в князе прямого предка суздальско-нижегородских князей, отца Василия Михайловича Суздальского, известного из Никоновской летописи [19, с. $177 ; 11$, c. $69-71 ; 12 ; 15$, с. $218 ; 16$, с. 207-208].

Однако прежде чем перейти к происхождению князя, необходимо напомнить об одном недоразумении: подмене Михаила Андреевича Михаилом Ярославичем в сообщении Софийской I летописи о событиях 1305 г. в Нижнем Новгороде [19, с. 204]. Затем эта правка была повторена в Воскресенской ле- тописи [20, с. 184]. Даже такой выдающийся исследователь, как А.Е. Пресняков, неверно понял, о каком Михаиле идет речь [8, с. 353, прим. 9]. В советской историографии подчеркивалось, что сам великий князь расправился с восставшими [2, с. 462; 21 , с. 119-120; 22, с. 192]. Однако, как заметил еще А.В. Экземплярский, а затем развил В.А. Кучкин, в летописном тексте было исправлено отчество с «Андреевич» на «Ярославич» [7, с. 388 , прим. 1086; 16, c. 207-208].

Действительно, в летописной статье 6813 года в начале сказано о приезде Михаила Ярославиче Тверского из Орды, ряде других событий, а затем снова о приезде Михаила Ярославича, но в Нижний Новгород и о его расправе над восставшими, убившими бояр [23, с. 184]. Очевидно, речь идет о разных князьях. Первый - титулуется как великий князь и к тому времени уже находится на Руси, начиная войну с московскими Даниловичами. Приехавший в Нижний Михаил действует совершенно иначе. Тем не менее в научной литературе и сегодня продолжает встречаться отождествление Михаила Андреевича с тверским князем во время событий в Нижнем Новгороде $[14$, с. $68 ; 23$, с. 322$]$ или колебание в вопросе: считать ли Михаила тверским князем или сыном Андрея Городецкого [24, с. 64].

Рассмотрим теперь те данные, которые мы знаем о сыновьях Андрея Ярославича и Андрея Александровича с именем Михаил. Первый упоминается в Никоновской летописи после смерти Андрея Ярославича, где сказано, что у него были сыновья Юрий и Михаил [25, с. 144]. Затем после смерти брата Юрия сказано, что он стал суздальским князем. Само княжение трактуется как «великое» [25, с. 157]. Только это поздняя летопись с неоднозначной репутацией упоминает Михаила. Действительно, в других летописях говорится только о смерти Юрия Андреевича 8 марта, но о его преемнике умалчивает [1, c. 152]. Нет его в синодиках [26; 27], родословных «Временника» [28, с. 226], «Бархатной книге», где мы не находим сына Андрея Ярославича Михаила, а только бездетного Юрия и Василия [29]. Это делает Михаила несколько сомнительным.

В то же время о сыне Андрея Александровича Михаиле мы знаем из двух источников. Это сообщение об освящении церкви в Вологде в августе 1303 г., где он упомянут вместе с отцом. Несмотря на ошибку в годе, трудно сомневаться, что речь идет именно о Михаиле Андреевиче [30, с. 251-252]. Но если первое упоминание еще можно трактовать иначе, то данные Ростовского соборного синодика, где он указан вместе с отцом, матерью Евдокией и братом Борисом («Великому князю Андрею Александровичю и княгине его Евдокее и сынома его Борису, Михаилоу вечная память»), оспорить невозможно 
Абуков С.Н

[26, с. 99]. Синодики - слишком авторитетный источник, чтобы можно было им пренебречь. Но кто же из Михаилов Андреевичей на самом деле женился в Орде и упоминается во время подавления народного восстания в Нижнем Новгороде в 1305 г.?

Думается, что это сын Андрея Городецкого. Некоторые доводы в его пользу привел В.А. Кучкин. Это упоминание в 1303 г. сына Михаила у городецкого князя, его появление в княжестве Андрея Александровича, совпадение отчества Михаила с именем Андрея Александровича [16, с. 208]. Их можно подкрепить дополнительными фактами. Но рассмотрим вначале аргументы противников этой версии. Так как считалось, что Андрей Александрович женился в 1294 г. на дочери ростовского князя Дмитрия Борисовича Василисе, то сторонники сына Андрея Ярославича свою аргументацию строили на невозможности женитьбы «князька» в 10-летнем возрасте [9, c. 19]. Сам летописный текст говорит о суровом наказании князем «крамольников», что опять-таки трудно согласуется с предполагаемыми действиями ребенка, каким был Михаил, если считать его сыном городецкого князя. Однако историков не смущал тот факт, что великому князю Андрею Александровичу было на момент брака с ростовской княжной около 40 лет и его женитьба могла быть явно не первой. Но мнения историков о двух браках князя отвергались.

Однако в свете дополнительных данных положение представляется совершенно иначе. Во-первых, это краткая запись на пасхальных таблицах со следами тверского и новгородского происхождения сборника XIV в. под 6779 г. о женитьбе некоего Андрея («Андр ожени») [31, с. 582]. Конечно, можно принять его за какое-нибудь лицо. Но этот человек был настолько известен, что автор записи не счел нужным давать уточнения, о ком идет речь. Так как другие социальные страты, включая бояр, не удостаивались сообщений о женитьбах, то такое упоминание могло быть посвящено кому-то из видных Рюриковичей. Поэтому версия о боярине Андрее Воротиславиче малоубедительна. Но в это время больше не было никого из князей с таким именем, кроме сына Невского, и тогда логично было бы отождествить его с Андреем Городецким, что и сделал историк Т.В. Гимон. То, что князь упомянут без титула, не должно смущать. Большинство князей в этих пасхальных таблицах указано без титула. Собственно, в них они и упоминаются. Из РСС, как мы помним, имя жены Андрея Евдокия [26, с. 99].

Таким образом, Михаил - это сын Андрея и Евдокии, и в 1305 г. ему было никак не 10 лет, а не менее 16-17 лет, что может объяснить его женитьбу и организацию репрессий против восставших в Нижнем Новгороде. Но это мог быть и второй брак князя, подобно тому, как повторные браки с Чингисидками заключили Федор Черный Ярославский, Константин (II) Ростовский, Юрий Московский $[7$, с. 83,$34 ; 15$, c. 213]. Тогда вместо юноши перед нами предстает мужчина 25-30 лет. Однако все же брак кажется первым. Михаил ни разу не упоминается в бурные годы отца, а только на церемонии освящения церкви, а это могли быть и дети [32, с. 51]. Отсутствие при освящении брата Бориса понятно: тот умер на Костроме шестью месяцами раньше [20, с. 183]. Если Борис Андреевич княжил при жизни отца в Костроме, как считал А.В. Экземплярский, то и Михаил мог также получить свой стол, например, тот же Нижний [7, с. 265].
Другое утверждение, что раз бояре после смерти Андрея Городецкого отъехали в Тверь, значит, у него не осталось наследника, опроверг еще С.М. Соловьев [15, с. 218-219]. Действительно, не все уехали к Михаилу Ярославичу. Вероятно, это были владимирские бояре, которые были связаны своими вотчинами с великим княжением. Представители местной правящей элиты остались и намеревалась служить сыну своего прежнего князя. Более того, есть прямое указание, чьими слугами были убитые бояре: «...избиша черныа люди бояръ княжь Андреевыхъ Александровичя» [25, с. 176]. Представляется естественным, что бояре находились в городе и ждали приезда своего князя из Орды. Только сюзерен мог наказать убийц в своих владениях, а не чужой князь.

Может быть, Нижний тогда представлял собой часть Суздальского княжества и появление Михаила Андреевича Ярославича было законным? Но нет. Никаких достоверных данных о единстве Суздаля, Городца и Нижнего Новгорода в этот период мы не имеем. Смутные указания не могут быть приняты в расчет и опровергаются летописными данными. Уязвимость своей версии сторонники Андрея Ярославича компенсировали предположением о передаче ханского ярлыка его сыну на «суздальские пригороды»Нижний Новгород [5, с. 13]. Но мы видим, что в Суздале правят свои князья, враждебные потомкам Александра Невского [1, с. 157; 32, с. 86]. Вероятно, в начале XIV в. это были Александр и Константин Васильевичи, хотя первое упоминание об Александре Суздальском относится только к 1328 г. [1, c. 168]. Нижний Новгород до этого они не контролировали и ярлыками на него не владели. Поэтому никак гипотетический Михаил Андреевич Ярославича не мог руководить в другом княжестве. Впрочем, нельзя исключить, что в середине XIII в. при Андрее Ярославиче Нижний Новгород и Городец входили некоторое время в число его владений, что было позднее использовано суздальскими князьями для обоснования своих прав [12].

Сама женитьба Михаила в Орде вполне в духе политики Андрея Городецкого, который безоглядно опирался на захватчиков в своей политике на Руси. Особенно ярко это проявилось в период борьбы с братом Дмитрием за великое княжение владимирское в 80-90-е гг. ХІІІ в. Нельзя не увидеть связи князей-татарофилов с ордынской элитой, которые они старались подкрепить браками с Джучидками во второй половине XIII - начале XIV вв. Вероятно, Михаил Андреевич не был исключением. Известно, как князья следовали традиционной политике своих отцов и дедов. В то же время у нас нет подобных фактов о первых суздальских князьях. Наоборот, Андрей Ярославич, как известно, в 1252 г. поднял восстание против Орды и только позднее был прощен ханом. Его слова, переданные летописцем, об отношении к татарам красноречиво говорят о его взглядах на ордынское иго [25, с. 138].

Очевидно, что Михаил Андреевич 1305 г. - это сын городецкого князя от первого брака. Об этом говорит его упоминание после смерти Андрея Александровича. Летописцы даже не посчитали нужным уточнить, о сыне какого Андрея идет речь - это было понятно. Логична в таком случае его поездка к хану на утверждение во владении и получении поддержки, его возвращение в Нижний Новгород, где он действует как энергичный и решительный правитель в подавлении выступления. 
Будь князь сыном Андрея Ярославича, о котором нет летописных известий более четверти века и который не известен родословным, то именно он должен был стать следующим по старшинству владимирским князем, а не Михаил Тверской. Однако никаких своих прав на великое княжение он не предъявляет и за Владимир не борется.

Что касается дальнейшей судьбы Михаила Андреевича Александровича, то трудно не согласиться с В.А. Кучкиным, который полагал его бездетную смерть, в результат чего в Нижнем Новгороде оказались московские князья [16, с. 206]. Их появление и настойчивые попытки отставить город за собой могли основываться на особых правах. Если считать его внуком Александра Невского, то именно двоюродные братья в Москве были его ближайшей родней. Тяга Даниила и его сыновей к выморочным владениям близких родственников можно проследить на примере Переславля Залесского, доставшегося Москве после смерти другого внука Александра Невского - Ивана Дмитриевича. Выбивать их оттуда пришлось великому князю.

Несколько слов необходимо сказать о князе «Василия Михайловиче Суздальском» Никоновской летописи, умершем в 1309 г. Целый ряд исследователей, на основании показаний все той же летописи, считали его сыном Михаила Андреевича и отцом суздальских князей Александра и Константина Васильевичей. Однако это ошибка и загадочный Василий Михайлович не имеет отношения к генеалогии суздальско-нижегородских князей. По данным синодика Успенского собора Московского кремля и хронологического расчета - отец Васильевичей князь Василий Андреевич, внук Андрея Ярославича [27, c. 445-446]. На это указывает и владельческое «суздальский», что связывает его с потомками Андрея Ярославича, а не Андрея Александровича. Если Василий Михайлович и существовал, то мог быть только внуком Андрея Ярославича. Более развернутая аргументация о происхождении суздальсконижегородских князей представлена в другой работе, и здесь нет смысла повторяться.

По нашему мнению, события выстраиваются так. 27 июля 1304 г. умирает великий князь Андрей Александрович, у которого остается в живых единственный сын Михаил от брака с первой женой Евдокией в возрасте около 17 лет. Возможно, еще при жизни отца он получил в удел Нижний Новгород. Князь едет в Орду после смерти родителя с целью получить ярлык на его удел. Понятно, что особых прав и больших шансов на борьбу за великое княжение владимирское у юного княжича не было, и здесь нет смысла предполагать его отказ [16, с. 131, прим. $35 ; 17$, с. 52]. Задача стояла в удержании за собой отчинных земель от посягательств сильных князей. Основная масса великокняжеских бояр отца подалась на службу в Тверь к его преемнику Михаилу Ярославичу Тверскому. В то же время часть местных бояр осталась служить Михаилу Андреевичу и ждала его возвращения от хана. Для укрепления своего положения князь в Орде вступает в брак с представительницей правящей ордынской элиты. Приехав в город, он суровой рукой подавляет бунт в Нижнем и наказывает его виновников. Само выступление народа против бояр следует рассматривать в связи с ослаблением власти, общей политической нестабильностью, тяжелым положением малоимущих слоев в городах Северо-Восточной Руси после смерти
Андрея Городецкого и началом борьбы за Владимир между Москвой и Тверью. Вероятно, что социальное недовольство этого времени, очевидность которого трудно отрицать, было подпитано еще и политическими причинами. Любопытно, что наиболее массовые выступления народа произошли в 1304 и 1305 гг. в Костроме и Нижнем Новгороде, где упоминаются сыновья великого князя Андрея [1, с. 393].

Отсутствие дальнейших упоминаний о Михаиле Андреевиче объясняется его ранней кончиной без наследника до 1311 г., что спровоцировало перманентный конфликт за его выморочные владения между московскими, тверскими и суздальскими князьями. При этом Москва позиционирует себя как законного наследника этих земель. Вероятно, что с 1319 по 1322 гг. нижегородские земли находились под властью Москвы, в период правления великих князей Дмитрия и Александра Михайловичей - Твери (13221327), 1328-1331 гг. - Суздаля, 1331-1342 - снова Москвы и с 1342 г. - Суздаля с образованием нового Суздальско-Нижегородского княжества в Поволжье.

Таким образом, несмотря на определенную традицию в историографии, нет никаких оснований считать Михаила Андреевича сыном Андрея Ярославича, который первый и последний раз упоминается в 1279 г. исключительно как суздальский князь, задолго до этих событий. Данные говорят о том, что это сын Андрея Александровича от первого брака, известный из источников. Его приезд в Нижний Новгород и решительные действия против мятежников следует рассматривать как возвращение в наследственную отчину, где он имел суверенные права после смерти отца. Его поездка в Орду и женитьба там - продолжение татарофильской политики Андрея Городецкого, направленной на усиление своих позиций. Его ранняя и бездетная смерть сделала выморочным Нижегородское княжество и привела к его временному захвату московскими князьями, как ближайшей родни. Однако в дальнейшем княжество попало под власть суздальских князей, которым удалось отстоять его в ходе соперничества с Москвой в начале 40-х гг. XIV в. Поволжье было закреплено Ордой за потомками Андрея Ярославича, что привело к образованию Суздальско-Нижегородского княжества.

\section{Список литературы:}

1. ПСРЛ. Московский летописный свод конца XV века / под ред. М.Н. Тихомирова. Т. 25. М.-Л.: Изд-во Академии наук СССР, 1949. 464 с.

2. ПСРЛ. Летописный сборник, именуемый летописью Авраамки. Т. 16. М., ЯРК. 2000. 252 с.

3. Черепнин Л.В. Образование Русского централизованного государства в XIV-XV вв. Очерки социально-экономической и политической истории Руси. Вып. 3. М.: Издательство социально-экономической литературы, 1960. 899 с.

4. Карамзин Н.M. История государства Российского. В 12-ти т. T. IV. М.: Наука, 1992. 480 с.

5. Храмцовский Н. Краткий очерк истории и описание Нижнего Новгорода. В 2-х ч. Ч. І. Нижний Новгород: Губернская типография, 1857. $127+31$ с.

6. Петров Н.П. История родов русского дворянства. В 2-х кн. Кн. 1. М.: Современник, 1991. 431 с.

7. Экземплярский А.В. Великие и удельные князья Северной Руси в татарский период с 1238 по 1505 гг. В 2-х т. Т. 2. СПб.: Типография Императорской Академии наук, 1891. 696 с.

8. Пресняков А.Е. Образование Великорусского государства. М.: Богородский Печатник, 1998. 496 с. 
9. Абрамович В.Г. Князья Шуйские и российский трон. Л.: Издательство Ленинградского университета, 1991. $192 \mathrm{c}$.

10. Филатов Н.Ф. Нижегородский край: факты, события, люди. НН: Нижегородский гуманитарный центр, 1997. $375 \mathrm{c}$.

11. Шматов Е.В. Суздальско-нижегородские великие князья и их родословие Ч. 1 // Нижегородская старина. 2008. № 18. С. 67-72.

12. Таловин Д.С. Князь Михаил Андреевич и Нижегородское Поволжье в начале XIV в. // Городецкие чтения: мат-лы всерос. науч.-практ. конф. «Александр Невский и его эпоха». Городец, 2000. Вып. 3.

13. Войтович Л.В. Княжа доба: портрети еліти. Біла церква: Видавець Олександр Пшонківський, 2006. $784 \mathrm{c}$.

14. Селезнев Ф.А. История Нижегородского края с древнейших времен до конца XVI в.: учебное пособие. НН: Издание Нижегородского университета, 2014. $198 \mathrm{c}$.

15. Соловьев С.М. История России с древнейших времен / отв. ред.: И.Д. Ковальченко, С.С. Дмитриев. В 18 книгах. Кн. II. М.: Мысль, 1988. 765 с.

16. Кучкин В.А. Формирование государственной территории Северо-Восточной Руси в X-XIV вв. М.: Наука, 1984. 350 с.

17. Пудалов Б.М. К вопросу о происхождении суздальских князей // Древняя Русь. Вопросы медиевистики. 2004. № 4. С. 46-53. 214 c.

18. Горский А.А. Москва и Орда. М.: Наука, 2003.

19. ПСРЛ. Софийская первая летопись старшего извода. Т. 6, вып. 1 / подг. текста С.Н. Кистерева и Л.А. Тимошиной, предисл. Б.М. Клосса. М.: ЯРК, 2000. $320 \mathrm{c}$.

20. ПСРЛ. Летопись по Воскресенскому списку. Т. 7. М.: ЯРК, 2001. 360 c.

21. Будовниц И.У. Поддержка объединительных усилий Москвы населением русских городов: Академику Борису Дмитриевичу Грекову ко дню семидесятилетия: сб. ст. М.: Изд-во АН СССР, 1952. C. $117-122$

\section{ORIGIN OF KNYAZ MIKHAIL ANDREEVICH CHRONICLE ARTICLE OF 1305}

(C) 2019

\section{Abukov Sergey Navilyevich, candidate of historical sciences, \\ associate professor of Historiography, Source Studies, Archeology and Methods of History Teaching Department Donetsk National University (Donetsk, Donetsk People's Republic)}

Abstract. Among many controversial issues of Russian genealogy, a special place belongs to the problem of Knyaz Mikhail Andreevich origin, the chronicle article of 1305. It is known that he was married in the Horde and came to Nizhny Novgorod, where he executed the insurgent residents. The problem of his origin is related to the early history of Suzdal-Nizhny Novgorod knyazes dynasty and the inheritance of power in Rus in those years. In general, the history of the Russian lands in the XIII-XIV centuries is poorly covered by sources, and each new fact complements our understanding of this period. The name of the father of the knyaz is not mentioned in the sources. There are two opposing opinions in the scientific literature that cannot be combined. Some historians consider this knyaz to be the son of Andrei Alexandrovich of Gorodets, others - Andrei Yaroslavich of Suzdal. In the paper the author, on the basis of a critical analysis of the sources and arguments of historians, comes to the conclusion that Mikhail Andreyevich is the son of Andrei of Gorodets, who came to the city of his father. This is indicated by the presence of his name in the synodics, his mention in those years, connection with the inheritance of the knyaz of Gorodets, the marriage policy, etc. On the contrary, Mikhail of Suzdal is mentioned long before 1305 and has nothing to do with Nizhny Novgorod, which was not yet a part of the Suzdal Principality at the beginning of the $14^{\text {th }}$ century. According to the author, the knyaz died early and was not the ancestor of the Suzdal knyazes.

Keywords: Mikhail Andreevich; Andrei Yaroslavich; Andrei Alexandrovich; Mikhail Yaroslavich; Vasily Mikhailovich; Suzdal; Nizhny Novgorod; Moscow; Suzdal-Nizhny Novgorod Principality; Horde; XIV century; problem; son; father; knyaz; dynasty; principality; power; city; origin; genealogy; kinship. 